\title{
Intensi Whistleblowing dalam Organizational Commitment dan Obedience Pressure Auditor
}

\author{
Naomi Gerallda ${ }^{1}$ \\ Fakultas Ekonomi dan Bisnis \\ Universitas Kristen Satya Wacana, \\ Indonesia \\ Email: gerallda80@gmail.com
}

\author{
Suzy Noviyanti ${ }^{2}$ \\ Fakultas Ekonomi dan Bisnis \\ Universitas Kristen Satya Wacana, \\ Indonesia
}

\begin{abstract}
ABSTRAK
Komitmen organisasi mendorong individu untuk bertindak positif seperti mematuhi aturan yang berlaku, memiliki tanggung jawab, dan menjaga hubungan baik dengan rekan profesinya. Namun seringkaliauditor menda patkan tekanan dari atasan untuk melakukan tindakan yang melanggar kode etik. Penelitianini bertujuan untuk mengetahui apakah niat auditor melakukan whistleblowing dipengaruhi oleh organizational commitment dan obedience pressure. Penelitian ini menggunakan desain eksperimental $2 \times 2$ between subject dengan menggunakan sampel 66 data auditor yang dapat diolah. Hasil penelitian menujukkan bahwa auditor memiliki niat untuk melakukan whistleblowing jika organizational commitment tinggi dan obedience pressure rendah.
\end{abstract}

Kata Kunci: Komitmen Organisasi; Tekanan Ketaatan, Whistleblowing.

\section{Auditor's Whistleblowing Intention in Organizational Commitment and Obedience Pressure}

\section{ABSTRACT}

Organizational commitment encourages individuals to act positively, such as by complying with applicable rules, having responsibilities, and maintaining good relations with their professional colleagues. However, auditors often get pressure from their superiors to take actions that violate the code of ethics. This study aims to determine whether the auditors' whistleblowing intention is influenced by organizational commitment and obedience pressure. This study used an $2 \times 2$ experimental design of $2 \times 2$ between subjects using the data obtained from a total of 66 auditors. The results show that the auditors had a whistleblowing intention if organizational commitment is high and obedience pressure low.

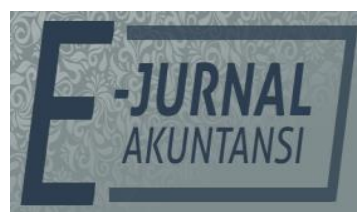

E-JA

e-Jurnal Akuntansi e-ISSN 2302-8556

Vol. 30 No. 6

Denpasar, Juni 2020

Hal.1470-1483

Artikel Masuk: 18 April 2020

Tanggal Diterima: 9 Juni 2020

Keywords: $\quad$ Obendience Pressure; Organizational Commitment; Whistleblowing.

This Article is Avalilable in: $h t t p s: / / o j s . u n u d . a c . i d / i n d e x . p h p / A k u n t a n s i / i n d e x$ 


\section{PENDAHULUAN}

Auditor independen merupakan akuntan publik yang menjalankan profesinya di Kantor Akuntan Publik. Tugas auditor melakukan pengaauditan laporan keuangan perusahaan berdasarkan kode etik yang telah di tetapkan (Sari \& Yustina, 2018). Dalam menjalankan tugasnya, auditor profesional harus berperilaku etis sesuai dengan etika profesi yang ditetapkan oleh Institut Akuntan Publik Indonesia (IAPI). Jalil (2014), menyatakan bahwa perilaku etis auditor merupakan penentuan reputasi dan kredibilitas atas profesinya di bidang akuntansi.

Pada kenyataannya, masih banyak skandal manipulasi keuangan yang dilakukan oleh Kantor Akuntan Publik dalam mengaudit laporan keuangan suatu perusahaan. Pratiwi (2019), menyatakan bahwa pada tanggal 1 April 2019 PT. Garuda Indonesia melaporkan kepada Bursa Efek Indonesia mengenai kinerja keuangan tahun 2018. Dalam laporan keuangan yang telah diaudit oleh Kantor Akuntan Publik (KAP) Tanubrata Sutanto Fahmi Bambang dan Rekan, PT. Garuda Indonesia pada tahun 2018 berhasil meraih laba bersih sebesar US\$809 ribu, hal ini berbanding terbalik dengan kerugian sebesar US\$216,58 juta yang dialami oleh PT. Garuda Indonesia pada tahun 2017. Dua komisaris Garuda Indonesia menolak untuk menandatangani laporan keuangan pada tahun 2018, serta penolakan pencatatan pendapatan atas transaksi kerjasama oleh PT. Mahata Aero Teknologi. Hal ini disebabkan karena belum ada pembayaran yang dilakukan oleh PT. Mahata pada tahun 2018.

Dari banyaknya kasus KAP yang tidak menjalankan tugasnya sesuai dengan kode etik yang ditetapkan, hal itu membuat kepercayaan publik memudar mengenai profesi akuntan publik (Barrainkua \& Espinosa-Pike, 2018). Maka, perlu adanya sistem yang digunakan untuk mengembalikan kepercayaan masyarakat dan sebagai pengendalian internal untuk pencegahan pelanggaran kode etik profesi yaitu dengan melakukan sistem whistleblowing. Alinaghian, Nasr Isfahani, \& Safari (2018), menyatakan bahwa whistleblowing merupakan pelaporan oleh karyawan perusahaan yang aktif maupun non aktif mengenai tindakan tidak bermoral, manipulasi atau pelanggaran, serta tindakan illegal kepada pihak internal maupun eksternal perusahaan. Hasil penelitian Business Ethics tahun 2007 menyatakan bahwa 50 persen individu yang mengetahui kecurangan hanya bersikap diam dan tidak melakukan tindakan pelaporan. Hal ini, mendorong pihak KNKG menetapkan whistleblowing di Indonesia pada tanggal 10 November 2008.

Whistleblowing merupakan suatu tindakan pelaporan yang dilakukan oleh individu dalam suatu organisasi terhadap praktik kecurangan maupun tindakan melanggar aturan yang dianggap tidak etis kepada pihak internal maupun eksternal organisasi (Ilham, 2016) dan (Dewi \& Ariyanto, 2019). Seseorang yang melakukan tindakan whistleblowing disebut dengan pelapor tindakan atau whistleblower (Indra, 2018). Semua anggota organisasi dapat menjadi seorang whistleblower (Dewi \& Ariyanto, 2019), namun pada umumnya seorang yang bekerja di dalam suatu organisasi akan mengalami adanya dilema etis antara melaporkan atau hanya berdiam dan membiarkan pelanggaran yang terjadi disekitarnya (Dewi \& Ariyanto, 2019). Karena hal itu, seorang dapat menjadi whistleblower apabila memiliki intensi dan keyakinan yang kuat di dalam dirinya 
(Dewi \& Ariyanto, 2019). Bernawati \& Napitupulu (2018) dan(Dewi \& Ariyanto, 2019), menyatakan bahwa intensi merupakan rencana individu untuk menunjukkan perilaku yang sesuai dengan sikapnya. Intensi dapat diwujudkan dalam perilaku aktual jika individu memiliki peluang yang baik dan waktu yang tepat dalam mewujudkannya. Intensi memiliki peranan yang sangat penting di dalam melakukan sistem whistleblowing. Semakin besar intensi individu, maka akan semakin besar intensi itu diaktualisasikan dalam bentuk tindakan (Dewi \& Ariyanto, 2019) dan (Helmayunita, 2018). Pelaporan whistleblowing dapat dilakukan secara internal maupun eksternal. Jalil (2014), menyatakan bahwa whistleblowing internal adalah pelaporan yang dilakukan oleh individu dalam suatu organisasi atas tindak penyelewengan yang tidak etis kepada pihak manajemen. Sedangkan, whistleblowing eksternal merupakan pelaporan yang dilakukan oleh individu dalam suatu organisasi atas perilaku kecurangan yang tidak etis kepada pihak eksternal organisasi maupun penegak hukum.

Meskipun banyak penelitian mengenai sistem whistleblowing di Indonesia, penelitian sebelumnya hanya meneliti faktor-faktor seseorang melakukan tindakan whistleblowing dikalangan pemerintah, karyawan, maupun mahasiswa diberbagai universitas (Dewi \& Ariyanto, 2019). Sedangkan, masih jarang pengujian intensi whistleblowing dikalangan Akuntan Publik. Auditor yang bekerja di Kantor Akuntan Publik harus mematuhi kode etik profesi dan standar profesional dalam menjalankan tugasnya terkait dengan audit laporan keuangan. Tindakan whistleblowing dapat dilakukan apabila auditor melihat adanya pelanggaran terhadap kode etik dan standar profesional yang dapat menimbulkan kesalahan dalam pemberian opini. Seorang auditor yang bekerja di Kantor Akuntan Publik memiliki organizational commitment di dalam menjalankan tugasnya. Menurut Elizabeth \& Friska (2013), komitmen organisasi merupakan bentuk loyalitas seorang karyawan terhadap organisasi dan bentuk kepedulian untuk kebaikan dan keberhasilan organisasi. Sehingga, organizational commitment merupakan salah satu faktor yang dapat menimbulkan intensi dalam diri auditor untuk melakukan tindakan whistleblowing. Seorang auditor juga akan sering berhubungan dengan auditor lain, manajer, maupun kliennya, maka akan rentan bagi auditor mengalami dilema etis antara tekanan yang di berikan berbagai pihak untuk kepentingan masing-masing individu dengan keyakinan dalam dirinya. Hal itu membuat auditor melakukan pertimbangan etis untuk menentukan keputusan yang harus diambil.

Penelitian ini mengacu pada penelitian (Setianto, Utami, \& Novianti, 2016) tentang whistleblowing dalam tekanan ketaatan dan kepercayaan pada pimpinan. Berbeda dengan penelitian tersebut, penelitian ini menambahkan variabel independen yaitu organizational commitment yang diterapkan pada auditor yang bekerja di Kantor Akuntan Publik Semarang. Pertimbangan pengujian kembali variabel organizational commitment dari beberapa penelitian terdahulu karena masih banyak ditemukan hasil pengujian variabel tersebut yang mengalami ketidakkonsistenan serta pengujian variabel organizational commitment di kalangan akuntan publik masih jarang ditemukan. Pemilihan auditor sebagai narasumber, karena dalam menjalankan tanggung jawab profesinya, auditor akan menemukan banyak pelanggaran yang terjadi disekitarnya yang akan membuat auditor mengalami dilema etis antara 
mengungkapkan atau membiarkan pelanggaran terjadi yang mengakibatkan kesalahan dalam pemberian opini audit.

Dengan adanya penelitian ini, diharapkan bermanfaat bagi kalangan Kantor Akuntan Publik dalam pertimbangan merekrut auditor dan penanaman kesadaran serta mendorong penerapan sistem whistleblowing bagi semua kalangan auditor yang ada di KAP. Penelitian ini juga diharapkan memberikan manfaat bagi pengembagan literatur terkhusus di bidang audit tentang faktor yang mempengaruhi intensi tindakan whistleblowing dan penanaman mengenai pentingnya sistem whistleblowing di kalangan mahasiswa sejak dini, sehingga mahasiswa yang telah menyelesaikan gelarnya dapat memberikan kontribusi yang baik di dunia profesinya.

Di dalam Theory of Planned Behaviour menjelaskan bahwa terdapat hubungan antara sikap dan perilaku seseorang. Pada dasarnya teori ini mengasumsikan bahwa setiap manusia akan berperilaku yang sesuai. Individu akan berperilaku karena adanya dorongan untuk melakukan hal tersebut. Ayu \& Pradnya (2019), menyatakan bahwa tujuan teori ini untuk dapat memperkirakan dan memahami pengaruh atas intensi beperilaku, mengidentifikasi cara agar dapat merubah perilaku, serta dapat menjelaskan perilaku manusia. Pada dasarnya manusia merupakan individu yang dapat berpikir secara rasional tentang segala informasi yang ada dan dapat mempertimbangkan dampak atas perilakunya tersebut sebelum memutuskan untuk melakukan tindakan. Wicaksono (2018), menyatakan bahwa Theory of Planned Behaviour di dasarkan pada tiga hal, yaitu (1) sikap terhadap suatu perilaku (terkait dengan dasar perilaku individu) yang menyatakan bahwa seorang individu akan merespon keadaan sosial disekitarnya, baik yang positif maupun negatif, (2) norma subyektif (terkait dengan adanya pengaruh secara sosial) yang merupakan pandangan individu mengenai individu lain yang bersikap di dalam kehidupannya, (3) kontrol perilaku yang dirasakan, yang menyatakan bahwa kontrol perilaku lebih mengacu dalam pandangan individu tentang kemampuannya untuk menampilkan perilaku tersebut.

Organizational commitment dan obedience pressure dapat menggambarkan tiga faktor munculnya intensi dalam diri seseorang yang mengarah pada keputusan yang diambil individu dalam berperilaku. Komponen norma subyektif dalam TPB dipresentasikan ke dalam variabel organizational commitment. Jika di dalam diri seorang individu memiliki komitmen terhadap organisasi maka terdapat keyakinan yang besar dalam mewujudkan tujuan organisasi serta menjaga reputasi organisasi tersebut. Individu yang memiliki komitmen yang tinggi akan bertindak secara cepat didalam mengatasi permasalahan kecurangan yang ada di organisasi, demi menjaga kelangsungan organisasi. Sedangkan variabel obedience pressure lebih mengaplikasikan terhadap komponen persepsi perilaku kontrol. Perilaku seorang auditor bisa saja tidak dapat dikendalikan oleh auditor itu sendiri melainkan adanya individu lain yang mengendalikan perilaku tersebut. Pengendalian terhadap perilaku auditor bisa disebabkan karena faktor internal maupun faktor eksternal. Obedience pressure lebih merujuk kepada pengendalian terhadap perilaku yang disebabkan oleh lingkungan yang ada di sekeliling individu tersebut (faktor eksternal). 
Setiap organisasi membutuhkan adanya komitmen organisasi sebagai pedoman bagi anggotanya dalam menjalankan tujuan organisasi (Indriani, Yulia, \& Ariska, 2019). Komitmen organisasi merupakan bentuk loyalitas dan perasaan memiliki terhadap suatu organisasi. Bernawati \& Napitupulu (2018) dan (Dewi \& Ariyanto, 2019), berpendapat bahwa seorang individu akan melakukan tindakan whistleblowing sebagai niatnya dalam melindungi organisasi dari kehancuran, apabila individu tersebut memiliki komitmen organisasi yang kuat. Seorang auditor yang memiliki komitmen organisasi tinggi akan memiliki pertimbangan etis mengenai tujuan dan keberlangsungan KAP tempat auditor bekerja sebelum mengambil suatu keputusan. Penelitian tersebut sejalan dengan Helmayunita (2018), yang menyatakan bahwa komitmen organisasi yang telah melekat dalam diri individu akan cenderung mengambil tindakan whistleblowing. Komitmen organisasi merupakan perpaduan antara sikap dan perilaku yang menyangkut tiga hal, yaitu adanya rasa peduli terhadap tujuan organisasi, adanya rasa keterlibatan di dalam aktivitas organisasi, serta adanya rasa melindungi organisasi dari ancaman yang ada. Pernyataan tersebut di dukung oleh penelitian Dekar et al. (2018), menyatakan bahwa jika terdapat masalah yang akan mengganggu tujuan organisasi, anggota yang memiliki komitmen organisasi kuat akan mencoba untuk menyelesaikan permasalahan tersebut dan mengarahkan organisasi dalam mencapai tujuannya. Berdasarkan argumentasi dan landasan teori, maka diajukan hipotesis pertama adalah :

$\mathrm{H}_{1}$ : Terdapat perbedaaan intensi whistleblowing pada auditor yang mempunyai Organizational Commitment tinggi dan rendah.

Rheny \& Fajar (2017), menyatakan bahwa status of wrongdoing merupakan anggota organisasi yang memiliki jabatan rendah akan sulit melaporkan kesalahan ataupun kecurangan yang dilakukan oleh anggota organisasi dengan jabatan yang lebih tinggi. Hal itu dikarenakan, individu di dalam organisasi yang memiliki jabatan lebih tinggi dapat menyalahgunakan wewenangnya untuk mengancam anggota organisasi yang memiliki jabatan lebih rendah (Dewi \& Ariyanto, 2019). Seringkali, hal ini terjadi di dalam suatu organisasi, individu dengan jabatan yang rendah akan lebih baik memilih untuk berdiam dan tidak melakukan whistleblowing atas perbuatan yang dilakukan oleh individu lain yang memiliki jabatan lebih tinggi di atasnya. Semakin besar jurang perbedaan antara jabatan individu tersebut, maka akan semakin tinggi tingkat ancaman bagi individu yang memiliki jabatan rendah. Ancaman tersebut dapat menjadi obedience pressure bagi individu jabatan rendah.

Obedience pressure merupakan sebuah perintah yang bersifat memaksa berasal dari atasan maupun klien yang mengharuskan individu tingkat bawah melakukan penyelewangan dari standar profesinya (Libriani \& Utami, 2015). Di dalam dunia profesi, auditor seringkali dihadapkan pada kondisi dilema etis. Auditor dihadapkan dengan dua pilihan yang berbeda antara kode etik profesi yang harus dijalankan di dalam tanggung jawab profesinya, serta auditor dapat mengalami obedience pressure dari pihak KAP maupun kliennya. Dalam menjalankan tanggung jawab profesinya, auditor akan menemukan ketidakwajaran di dalam laporan keuangan entitas yang sedang di auditnya. Sedangkan, entitas menginginkan pernyataan yang wajar terhadap laporan keuangannya. Maka, seringkali auditor mendapatkan perintah secara paksa 
untuk merubah opininya atas laporan keuangan entitas tersebut. Banyak auditor yang memilih untuk diam ketika mengetahui kecurangan terjadi disekelilingnya. Perintah paksaan yang dilakukan oleh pihak-pihak eksternal dapat membuat auditor tidak memiliki intensi whistleblowing (Dewi \& Ariyanto, 2019). Hasil penelitian Febrina (2015), menyatakan bahwa auditor seringkali melanggar kode etiknya, karena adanya perintah yang memaksa dari pihak atasan di dalam suatu KAP maupun entitas yang sedang diauditnya. Hal ini sejalan dengan penelitian Setianto, Utami, \& Novianti (2016), bahwa obedience pressure dapat membuat auditor menghilangkan tanggung jawab pada kode etik yang dianutnya dalam mengambil suatu tindakan.

Berdasarkan argumentasi dan landasan teori, maka diajukan hipotesis kedua adalah :

$\mathrm{H}_{2}$ : Terdapat perbedaaan intensi whistleblowing pada auditor yang mempunyai Obedience pressure tinggi dan rendah.

\section{METODE PENELITIAN}

Populasi penelitian ini adalah auditor independen yang bekerja di Kantor Akuntan Publik Semarang. Pengambilan sampel dalam penelitian ini dengan menggunakan convenience sampling yang di dasarkan atas pertimbangkan dalam kemudahan mendapatkan informasi serta menjalin kedekatan dengan responden. Penelitian ini menggunakan metode penelitian kuantitatif dan pengambilan data dilakukan secara langsung (data primer) berupa pembagian kuesioner pada KAP di Semarang.

Penelitian ini menggunakan desain penelitian studi eksperimental $2 \times 2$ between subject. Penelitian ini menggunakan organizational commitment dan obedience pressure sebagai variabel independen, serta intensi whistleblowing sebagai variabel dependen. Penelitian ini melibatkan subjek eksperimen yaitu semua tingkatan auditor di Kantor Akuntan Publik Semarang. Pemilihan auditor sebagai subjek eksperimen karena auditor lebih mampu memahami, mengobservasi, dan memiliki pengetahuan luas tentang kecurangan yang ada di dalam menjalankan profesinya.

Desain penelitian ini mengacu pada desain penelitian Setianto et al. (2016) yang membuat manipulation check untuk variabel tekanan ketaatan dan kepercayaan kepada pimpinan dalam melakukan tindakan whistleblowing dengan subjek penelitian mahasiswa S1 Akuntansi Universitas Kristen Satya Wacana. Penelitian yang sama dilakukan oleh Cahyaningrum, Ayuananda, \& Arifin (2017), yang membuat desain penelitian eksperimen dengan subjek penelitian yaitu mahasiswa S1 Akuntansi Universitas Pelita Harapan. Alur penelitian ini mengacu pada beberapa alur penelitian yang sudah ada, namun penerapan desain penelitian ini telah di modifikasi dan juga terdapat perbedaan dalam subjek penelitian.

Auditor sebagai subjek di dalam eksperimen berperan sesuai dengan profesinya. Kantor Akuntan Publik tempat auditor bekerja sedang melakukan audit atas suatu perusahaan. Auditor dihadapkan pada situasi dimana mendapatkan perintah dari partner in change dalam suatu proyek. Sehingga, mengakibatkan opini yang ada di dalam laporan audit tidak mencerminkan yang 
sesungguhnya. Auditor memiliki kesempatan untuk mengungkapkan pelanggaran yang terjadi kepada manajer maupun pihak berwenang.

Proses eksperimen melalui 6 tahapan, Gambar 1:

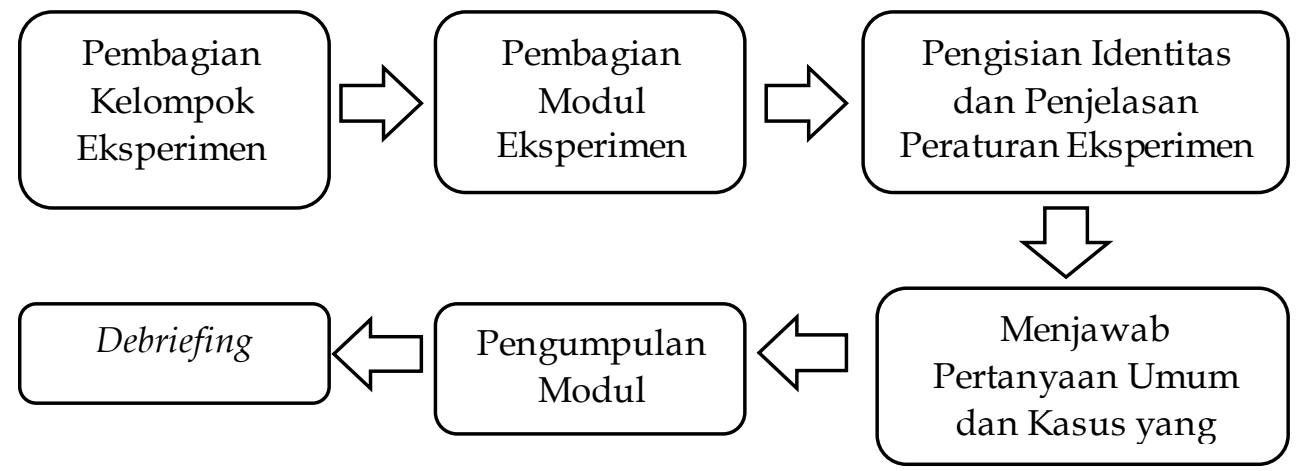

Sumber: Setianto et al., 2016

Gambar 1. Alur Eksperimen

Subjek dibagi menjadi dua kelompok eksperimen secara acak dan mendapatkan perlakuan yang berbeda. Kelompok pertama mendapatkan modul A dengan obedience pressure yang tinggi, lalu kelompok kedua mendapatkan modul B dengan obedience pressure yang rendah. Sedangkan variabel organizational commitment terdiri dari 9 pertanyaan menggunakan skala likert yang dapat menghasilkan organizational commitment tinggi maupun rendah. Matriks desain penelitian eksperimen dijelaskan pada Tabel 1.

\section{Tabel 1. Experiment Group Design}

\begin{tabular}{llll}
\hline & & \multicolumn{2}{c}{ Organizational Commitment } \\
\cline { 2 - 4 } & & Tinggi & Rendah \\
\hline Obedience Pressure & Tinggi & Kelompok 1 & Kelompok 2 \\
\cline { 2 - 4 } & Rendah & Kelompok 3 & Kelompok 4 \\
\hline
\end{tabular}

Sumber: Setianto et al., 2016

Dari Tabel 1, subjek eksperimen mendapatkan pertanyaan mengenai variabel organizational commitment dengan menggunakan skala likert 1 (Sangat Tidak Setuju) sampai dengan 5 (Sangat Setuju). Sedangkan, untuk variabel obedience pressure dibagi menjadi dua tipe modul. Pada modul A, auditor dihadapkan pada obedience pressure yang tinggi dari partner in change dari suatu proyek yang di kerjakan oleh KAP. Sedangkan, pada modul B auditor dihadapkan pada situasi partner in change yang tidak terlalu ketat dalam pengawasan staff kantornya dan bersikap ramah pada setiap karyawan (obedience pressure rendah). Subjek eksperimen hanya diberikan waktu selama lima belas menit untuk mengerjakan modul. Setiap kelompok subjek eksperimen diharapkan dapat menyelesaikan semua pertanyaan yang telah tersedia walaupun mengalami perlakuan kasus yang berbeda. Subjek eksperimen yang telah selesai mengerjakan modul dapat dikumpulkan. Setelah eksperimen telah dilakukan, peneliti akan mengembalikan kondisi subjek eksperimen seperti semula sebelum suasana di manipulasi (debriefing).

Teknik analisis data pada tahap pertama dilakukan pengujian profil subjek dengan statistik deskriptif. Pada tahap kedua, sebelum melakukan pengujian hipotesis maka perlu dilakukan pengujian randomisasi atas demografi untuk profil subjek dengan menggunakan Uji One Way Anova. Dilakukannya 
pengujian tersebut guna untuk mengetahui apakah adanya faktor secara demografi yang dapat mempengaruhi pengambilan keputusan. Pada tahap ketiga untuk menguji hipotesis dalam penelitian ini menggunakan Uji Two Way Analysis of Variance (ANOVA). Hipotesis terdukung jika nilai probabilitas di bawah 0,05 yang artinya terdapat perbedaan yang signifikan.

Variabel dalam penelitian ini terdiri dari variabel terikat $(\mathrm{Y})$ adalah intensi whistleblowing yang di ukur dengan menggunakan skala likert. Indriani et al. (2019), menyatakan bahwa intensi whistleblowing merupakan keinginan kuat yang berasal dari diri individu untuk melakukan suatu tindakan. Indikator dari intensi whistleblowing adalah melaporkan pelanggaran yang terjadi, tingginya tingkat keseriusan pelaporan, dan persepsi positif tentang whistleblowing.

Variabel bebas $(X)$ yang digunakan dalam penelitian ini adalah organizational commitment dan obedience pressure. Dekar et al. (2018), menyatakan bahwa komitmen organisasi merupakan suatu bentuk loyalitas dan perasaan memiliki individu terhadap suatu organisasi. Indikator organizational commitment adalah bangga dengan organisasi, berusaha mencapai tujuan organisasi, patuh pada pedoman organisasi, berpartisipasi aktif dalam organisasi, serta loyalitas. Variabel organizational commitment di ukur menggunakan skala likert.

Berbeda hal dengan variabel bebas obedience pressure dimanipulasi dengan memberikan pernyataan dalam kasus eksperimen. Eka \& Intiyas (2015), menyatakan bahwa obedience pressure merupakan sebuah perintah yang bersifat memaksa yang berasal dari atasan maupun klien yang mengharuskan individu melakukan penyelewengan dari standar profesinya. Indikator dari obedience pressure adalah adanya perintah yang melanggar pedoman organisasi, standar audit, kode etik dan juga adanya sanksi yang berat jika tidak mengikuti perintah atasan. Pertanyaan untuk variabel organizational commitment dapat diukur dengan menggunakan skala likert 1 (Sangat Tidak Setuju) sampai dengan 5 (Sangat Setuju). Untuk variabel obedience pressure menggunakan manipulasi dengan dibuatkan dua tipe modul.

Pada modul A, subjek dimanipulasi dengan dihadapkan pada obedience pressure yang tinggi dari partner in change dari suatu proyek yang di kerjakan oleh KAP. Subjek berperan sebagai auditor yang bekerja di suatu Kantor Akuntan Publik dengan memiliki tiga partner. Pimpinan partner mereka selalu bekerja sesuai etika profesi yang telah ditetapkan. Subjek saat itu sedang melakukan proses audit atas perusahaan manufaktur dengan partner in charge yang memiliki sikap otoriter dan selalu mengutamakan kepentingan klien meskipun hal itu melanggar etika profesi. Perintah dari partner in charge tersebut harus dilakukan oleh semua staff di bawahnya. Staff yang tidak mengikuti perintahnya akan beresiko kehilangan pekerjaannya, karena dianggap staff tersebut tidak memiliki ketaatan terhadap atasan. Hal ini mengakibatkan terjadinya kesalahan opini audit yang dihasilkan. Sedangkan pada modul B, subjek dimanipulasi dengan dihadapkan pada obedience pressure rendah. Berbeda dari modul A, dalam modul $B$ ini subjek mengaudit sebuah perusahaan manufaktur dengan partner in charge yang memiliki sikap ramah dan tidak terlalu ketat terhadap staffnya. 


\section{HASIL DAN PEMBAHASAN}

Sasaran sampel dalam penelitian ini adalah auditor yang bekerja di Kantor Akuntan Publik Semarang. Seluruh sampel yang digunakan dalam penelitian ini adalah semua kalangan auditor yang bersedia untuk menjadi responden dengan cara mengisi kuesioner yang telah disediakan. Total sampel yang disebar untuk semua kalangan auditor yang bekerja di Kantor Akuntan Publik Semarang adalah 70 kuesioner. Namun kuesioner yang kembali dan dapat diolah hanya sebanyak 66 kuesioner. Jumlah sampel yang digunakan dalam penelitian ini hanya kuesioner yang telah diisi dengan lengkap oleh responden dan juga responden yang telah lolos dari soal pre-test. Demografi dari subjek eksperimen terdiri dari usia, jenis kelamin, jabatan fungsional, pendidikan terakhir dan lama waktu bekerja auditor di Kantor Akuntan Publik.

Subjek yang telah berpatisipasi di dalam eksperimen dengan usia di bawah 25 tahun sebanyak 15 orang (22,7\%), usia 26-35 tahun sebanyak 31 orang $(47 \%)$, usia $36-55$ tahun sebanyak 16 orang $(24,2 \%)$, serta subjek eksperimen yang memiliki usia di atas 55 tahun sebanyak 4 orang (6,1\%). Mayoritas subjek eksperimen berjenis kelamin laki-laki sebanyak 41 orang $(62,1 \%)$ dan untuk subjek wanita berjumlah 25 orang $(37,9 \%)$. Semua jabatan fungsional auditor yang berada di Kantor Akuntan Publik Semarang berpartisipasi di dalam penelitian eksperimen ini seperti auditor yunior dengan partisipan sebanyak 23 orang $(34,8 \%)$, auditor senior sebanyak 18 orang $(27,3 \%)$, jabatan supervisor auditor dengan partisipan sebanyak 15 orang $(22,7 \%)$, serta 10 orang $(15,2 \%)$ yang memiliki jabatan sebagai partner. Jumlah tertinggi dari pendidikan terakhir yang telah di tempuh auditor adalah S1 (Sarjana) dengan jumlah 45 orang $(68,2 \%)$, untuk auditor yang pendidikan terakhir di bawah S1 terdapat 3 orang $(4,5 \%)$, sementara itu auditor yang memiliki pendidikan terakhir S2 (Master) sebanyak 15 orang $(22,7 \%)$, serta auditor yang memiliki pendidikan terakhir S3 (Doktoral) sebanyak 3 orang (4,5\%). Dari hasil pengecekkan demografi subjek eksperimen, ditemukan bahwa auditor yang bekerja di KAP dengan masa kerja 0-2 tahun berjumlah 12 orang (18,2\%), untuk masa kerja 2-5 tahun berjumlah 24 orang $(36,4 \%)$, auditor yang memiliki masa kerja 5-10 tahun sebanyak 16 orang $(24,2 \%)$, serta auditor yang telah bekerja lebih dari 10 tahun sebanyak 14 orang $(21,2 \%)$.

Sebanyak 66 partisipan subjek eksperimen berperan sesuai dengan profesinya sebagai auditor di Kantor Akuntan Publik Havana \& Rekan. Subjek memiliki pimpinan partner yang selalu bekerja sesuai dengan etika profesi. Kantor Akuntan Publik tempat subjek bekerja sedang melakukan audit pada sebuah perusahaan manufaktur PT. Gesit Untung, dengan fee audit yang sangat besar. Subjek memiliki partner in change yang bersikap otoriter dan selalu mengutamakan kepentingan klien meskipun hal tersebut melanggar etika profesi. Dari hasil audit subjek pada PT. Gesit Untung, ditemukan bukti-bukti salah saji material. Namun, subjek diperintahkan oleh partner in change untuk merubah kertas kerja hasil pemeriksaan dan opini audit. Pada tahap pertama, subjek dibagi menjadi 2 kelompok yang berbeda. Masing-masing kelompok mendapatkan perlakuan tekanan ketaatan yang berbeda. Pada awal penugasan, masing-masing kelompok menjawab pertanyaan umum mengenai variabel organizational commitment yang berjumlah 9 pertanyaan dengan menggunakan 
skala likert, lalu masing-masing kelompok mendapatkan modul yang berbeda dengan perlakuan tekanan ketaatan tinggi maupun rendah. Berdasarkan pertanyaan tersebut, subjek eksperimen diminta untuk memberikan penilaian atas suatu keputusan pelaporan kepada jenjang yang lebih tinggi.

Setelah melakukan pengujian demografi subjek, maka perlu dilakukannya pengujian randomisasi atas demografi untuk profil subjek dengan menggunakan Uji One Way Anova pada Tabel 2.

Tabel 2. Hasil Uji One Way Anova

\begin{tabular}{|c|c|c|c|}
\hline \multirow{2}{*}{\multicolumn{4}{|c|}{ Keterangan }} \\
\hline & & & \\
\hline Between Groups & 0,604 & 0,692 & Tidak Berpengaruh \\
\hline Within Groups & 0,749 & & \\
\hline \multicolumn{4}{|l|}{ Jenis Kelamin : } \\
\hline Between Groups & 0,345 & 0,052 & Tidak Berpengaruh \\
\hline Within Groups & 0,192 & & \\
\hline \multicolumn{4}{|l|}{ Jabatan Fungsional } \\
\hline Between Groups & 1,186 & 0,456 & Tidak Berpengaruh \\
\hline Within Groups & 1,158 & & \\
\hline \multicolumn{4}{|c|}{ Pendidikan Terakhir: } \\
\hline Between Groups & 0,368 & 0,552 & Tidak Berpengaruh \\
\hline Within Groups & 0,394 & & \\
\hline \multicolumn{4}{|l|}{ Lama Bekerja : } \\
\hline Between Groups & 0,918 & 0,674 & Tidak Berpengaruh \\
\hline Within Groups & 1,114 & & \\
\hline
\end{tabular}

Sumber: Data Penelitian, 2020

Berdasarkan hasil pengujianTabel 2, kelima indikator yang telah ditentukan tidak memenuhi nilai significancy (Sig.) lebih kecil dari alpha $(0,05)$, sehingga dapat disimpulkan bahwa usia, jenis kelamin, jabatan fungsional, pendidikan terakhir, dan lama waktu bekerja tidak mempengaruhi penilaian atas niat untuk melakukan tindakan whistleblowing yang diberikan oleh auditor. Dengan demikian, randomisasi dapat dikatakan efektif karena hanya perlakuan yang mempengaruhi niat untuk melakukan whistleblowing auditor.

Sebelum melakukan pengujian hipotesis menggunakan Uji Two Way Anova, maka dilakukan terlebih dahulu uji normalitas dan homogenitas. Uji normalitas berguna untuk menguji apakah dalam model variabel terikat dan variabel bebas berdistribusi dengan normal atau tidak. Pengujian ini menggunakan uji statistik Kolmogorov-Smirnov (K-S). Data dapat dikatakan berdistribusi normal jika nilai signifikansi lebih besar dari 0,05, sedangkan data dikatakan tidak berdistribusi normal apabila nilai signifikansi kurang dari 0,05 (Arifin, 2017).

Tabel 3. Hasil Uji Tes Normalitas

\begin{tabular}{|c|c|c|c|c|c|c|}
\hline & \multicolumn{3}{|c|}{ Kolmogorov-Smirnov $a$} & \multicolumn{3}{|c|}{ Shapiro-Wilk } \\
\hline & Statistic & $\overline{D f}$ & Sig. & Statistic & $d f$ & Sig. \\
\hline $\begin{array}{l}\text { Standardized } \\
\text { Residual for } \\
\text { Intention } \\
\text { Whistleblowing }\end{array}$ & 0,058 & 66 & $0,200^{*}$ & 0,980 & 66 & 0,369 \\
\hline
\end{tabular}


Dari hasil Tabel 3 menunjukkan bahwa nilai signifikan KolmogorovSmirnov menunjukkan nilai 0,200 yang berarti lebih besar dari 0,05. Sehingga, data dapat dikatakan telah terdistribusi dengan normal dan dapat melakukan pengujian selanjutnya.

Setelah melakukan uji normalitas maka akan dilakukan pengujian homogenitas yang berguna untuk mengetahui apakah data dalam variabel $\mathrm{X}$ dan Y bersifat homogen atau tidak (Dzulasri, 2015). Dapat dikatakan bahwa varian sama secara signifikan (homogen) apabila nilai signifikansi lebih dari 0,05. Sedangkan, varian berbeda secara signifikan (tidak homogen) apabila nilai signifikansi kurang dari 0,05.

Tabel 4. Hasil Uji Tes Homogenitas

\begin{tabular}{cccc}
\hline \multicolumn{4}{c}{ Levene's Test of Equality of Error Variances $^{a}$} \\
Dependent Variable: & Intensi Whistleblowing \\
\hline $\mathrm{F}$ & $\mathrm{df1}$ & $\mathrm{df} 2$ & Sig. \\
0,772 & 3 & 62 & 0,514 \\
\hline
\end{tabular}

Sumber: Data Penelitian, 2020

Dari Tabel 4. menunjukkan bahwa nilai signifikan Levene's Statistic sebesar 0,514 yang berarti lebih besar dari 0,05. Hal ini dapat disimpulkan bahwa kedua variabel memiliki data yang homogen.

Hipotesis 1 pada penelitian ini menyatakan bahwa semakin tinggi organizational commitment yang di terima oleh responden, maka akan semakin besar potensi responden untuk memiliki niat melakukan tindakan whistleblowing. Sedangkan hipotesis ke-2 dalam penelitian ini menyatakan bahwa semakin tinggi obedience pressure yang di terima oleh responden, maka akan semakin besar potensi responden untuk memiliki niat dalam melakukan tindakan whistleblowing. Pengujian kedua hipotesis ini menggunakan Uji Two Way Anova seperti yang dijelaskan pada Tabel 5.

Tabel 5. Hasil Pengujian Hipotesis 1 \& 2

\begin{tabular}{|c|c|c|c|c|c|}
\hline \multicolumn{6}{|c|}{$\begin{array}{c}\text { Tests of Between-Subjects Effects } \\
\text { Dependent Variable: Intensi Whistleblowing }\end{array}$} \\
\hline Source & $\begin{array}{l}\text { Type III Sum } \\
\text { of Squares }\end{array}$ & $D f$ & Mean Square & $F$ & Sig. \\
\hline Corrected Model & $33356,241^{a}$ & 3 & 11118,747 & 3,528 & 0,020 \\
\hline Intercept & 4695279,143 & 1 & 4695279,143 & 1489,642 & 0,000 \\
\hline Organizational Commitment & 16841,847 & 1 & 16841,847 & 5,343 & 0,024 \\
\hline Obedience Pressure & 4656,765 & 1 & 4656,765 & 1,477 & 0,229 \\
\hline $\begin{array}{l}\text { Organizational Commitment* } \\
\text { Obedience Pressure }\end{array}$ & 942,080 & 1 & 942,080 & 0,299 & 0,587 \\
\hline Error & 195421,032 & 62 & 3151,952 & & \\
\hline Total & 5727300,000 & 66 & & & \\
\hline Corrected Total & 228777,273 & 65 & & & \\
\hline
\end{tabular}

Sumber: Data Penelitian, 2020

Berdasarkan Tabel 5 hasil pengujian statistik menjelaskan bahwa variabel organizational commitment memiliki nilai signifikansi sebesar 0,024 , yang berarti bahwa nilai signifikansi tersebut kurang dari 0,05, sehingga dapat dikatakan bahwa hipotesis 1 di terima karena responden memiliki niat untuk melakukan tindakan whistleblowing jika responden memiliki organizational commitment yang tinggi di dalam dirinya di bandingkan dengan potensi responden untuk 
melakukan tindakan whistleblowing dalam kondisi organizational commitment yang rendah.

Hal ini membuktikan, bahwa auditor menjadikan komitmen organisasi sebagai pedoman untuk melakukan tindakan etis di dalam menjalankan tanggung jawab profesinya pada suatu KAP. Auditor yang memiliki komitmen organisasi yang tinggi sadar bahwa ancaman yang ada di dalam tempat dia bekerja akan berdampak pula bagi profesinya, sehingga auditor akan timbul niat untuk melakukan tindakan whistleblowing. Penelitian ini sejalan dengan hasil penelitian Setiawati \& Sari (2016), yang menyatakan bahwa individu yang memiliki organizational commitment tinggi dalam suatu organisasi cenderung lebih mengutamakan tujuan dan kepentingan organisasi daripada kepentingan individu itu sendiri. Begitu juga dengan penelitian Dekar et al. (2018), yang menyatakan bahwa komitmen organisasi merupakan suatu bentuk loyalitas dan perasaan memiliki individu terhadap suatu organisasi. Komitmen organisasi juga di anggap sebagai cerminan sikap individu dalam mengenal dan terikat pada suatu organisasi (Rosiana \& Pradnya, 2019)

Hasil pengujian statistik juga menjelaskan bahwa variabel kedua yaitu obedience pressure memiliki nilai signifikansi sebesar 0,229 yang berarti bahwa nilai signifikansi tersebut lebih besar dari pada alpha 0,05. Sehingga, dapat dikatakan bahwa hipotesis kedua dalam penelitian ini di tolak. Penolakan hipotesis kedua ini karena auditor dalam melakukan tugasnya harus menerapkan etika profesi. Jadi meskipun ada tekanan tinggi dari atasan, auditor tetap akan menjalankan tanggung jawab profesinya secara profesional.

Ketika auditor mengalami tekanan tinggi yang berasal dari partner in charge yaitu pemecatan staff bagi yang tidak mengikuti perintahnya, auditor tidak merasakan adanya tekanan tersebut. Dengan adanya pertimbangan etis, auditor memiliki keyakinan dan pedoman yang kuat di dalam dirinya bahwa auditor harus menjalankan tanggung jawabnya sesuai dengan kode etik yang telah ditetapkan. Auditor akan tetap memiliki niat untuk melakukan tindakan whistleblowing walaupun akan berdampak negatif bagi profesinya. Hal ini sejalan dengan penelitian Valen (2018), yang menyatakan bahwa sikap profesional dalam diri auditor merupakan hal yang penting dalam menjalankan tanggung jawab profesinya, sehingga dapat menghasilkan audit yang berkualitas. Penelitian yang sama dilakukan oleh Barlet (2019), yang menyatakan bahwa kode etik ataupun etika profesi mengarahkan pada sikap, tingkah laku, dan perbuatan auditor dalam menjalankan tanggung jawab profesinya dengan mempertahankan kualitas mutu dari diri auditor. Jika seseorang telah menerima prinsip moral, maka prinsip tersebut merupakan bagian dari kode etik di dalam dirinya sendiri sehingga memotivasi diri untuk berpikir dan bertindak sesuai dengan prinsip tersebut (Barlet, 2019).

\section{SIMPULAN}

Hasil dari pengujian yang pertama, menunjukkan bahwa organizational commitment berpengaruh signifikan terhadap niat auditor untuk melakukan tindakan whistleblowing. Auditor yang memiliki organizational commitment yang tinggi akan cenderung memiliki niat untuk melakukan tindakan whistleblowing dibandingkan dengan auditor yang memiliki organizational commitment yang 
rendah. Komitmen organisasi membuat auditor mengutamakan segala tujuan dan kepentingan KAP di bandingkan dengan kepentingan individu itu sendiri. Kedua, obedience pressure yang terjadi pada auditor tidak memiliki pengaruh signifikan terhadap niat auditor untuk melakukan tindakan whistleblowing. Meskipun auditor mendapatkan tekanan ketaatan tinggi yang berasal dari atasan, auditor akan tetap melakukan tindakan whistleblowing walaupun berdampak negatif bagi profesinya, karena dalam menjalankan tanggung jawab profesinya auditor harus menerapkan etika profesi secara profesional.

Keterbatasan dalam penelitian ini adalah menggunakan metode eksperimen yang mengakibatkan ketidakmampuan peneliti dalam mengontrol responden. Selain itu, adanya kemungkinan terjadinya kesalahpahaman mengenai pandangan dan pemahaman terhadap treatment yang disajikan oleh peneliti. Saran bagi penelitian yang akan datang, sebaiknya pada awal eksperimen dilakukan pengujian karakteristik pada masing-masing individu tentang pengetahuannya terhadap whistleblowing. Penelitian selanjutnya diharapkan menambahkan variabel lain seperti pertimbangan etis yang memungkinkan adanya keterkaitan dengan intensi seseorang melakukan whistleblowing dan dapat memperluas daerah penelitian ke berbagai KAP tidak hanya di Semarang.

\section{REFERENSI}

Alinaghian, N., Isfahani, A. N., \& Safari, A. (2018). Factors influencing whistleblowing in the Iranian health system. Journal of Human Behavior in the Social Environment, $28(2)$, 177-192. https://doi.org/10.1080/10911359.2017.1349703

Arifin, J. (2017). SPSS 24 untuk Penelitian dan Skripsi. Jakarta.

Barlet, H. (2019). Pengaruh kecerdasan emosional, intelektual dan etika profesi terhadap kinerja auditor pada Kantor Akuntan Publik Jakarta Timur. Penelitian Akuntansi, 1(1), 59-67.

Barrainkua, I., \& Espinosa-Pike, M. (2018). The influence of auditors' professionalism on ethical judgement: differences among practitioners and postgraduate students. Revista de Contabilidad, 21(2), 176-187. https://doi.org/10.1016/j.rcsar.2017.07.001

Bernawati, Y., \& Napitupulu, G. B. (2018). The effect of organizational, induvidual, and demographic factors on the whistleblowing intention. Joumal of Accounting and Strategic Finance, 1(01), 1-12. https://doi.org/https://doi.org/10.33005/jasf.vli01.21

Cahyaningrum, C. D., Ayuananda, T. I., \& Arifin. (2017). Whistleblowing: studi eksperimental dalam kejujuran dan tekanan ketaatan. Journal of Accounting E Management Innovation, 1(2), 143-158.

Dekar, U., Briyan, S., \& Aditya, W. (2018). Whistleblowing intention: the effects of moral intensity, organizational and professional commitment. Jurnal Akuntansi, 22(3), 354-367. https://doi.org/10.24912/ja.v22i3.393

Dewi, A. A., \& Ariyanto, D. (2019). "Koh Ngomong" and A Desire to Do Whistleblowing: An Experimental Study. Journal of Accounting and Investment, 20(2). https://doi.org/10.18196/jai.2002122

Dzulasri, W. (2015). Pengaruh budaya dan gender terhadap keputusan akuntan 
(studi eksperimentasi semu pada mahasiswa akuntansi di Kota Padang dan Madura), 1-24.

Elizabeth, H., \& Friska, F. (2013). Faktor-faktor yang memengaruhi kinerja auditor. Jurnal Bisnis Dan Akuntansi, 15(1), 13-28.

Febrina, P. (2015). Pengaruh pengetahuan auditor, pengalaman auditor, kompleksitas tugas, locus of control, dan tekanan ketaatan terhadap audit judgment (studi kasus pada perwakilan BPKP provinsi Riau). Jom Fekon, 2(2), 1-15.

Helmayunita, N. (2018). The influence of personal cost of reporting, organizational commitment, fraud seriousnesss level, and gender on intentions to whistleblowing. Business and Management Research, 57(Piceeba), 42-49. https://doi.org/10.2991/piceeba-18.2018.77

Ilham, S. (2016). Pengaruh sikap dan persepsi kontrol perilaku terhadap niat whistleblowing internal-eksternal dengan persepsi dukungan organisasi sebagai variabel pemoderasi. Jurnal Akuntansi Dan Investasi, 17(2), 209-219. https://doi.org/10.18196/jai.2016.0056.209-219

Indra, S. (2018). Analisis persepsi mahasiswa terhadap niat melakukan whistleblowing. Jurnal Penelitian Ekonomi Dan Bisnis, 3(1), 1-11.

Indriani, M., Yulia, A., \& Ariska, L. P. (2019). Whistleblowing intention, personal cost , organizational commitment and fraud seriousness level. Accounting and Investment, 20(2), 129-151. https://doi.org/10.18196/jai.2002121

Jalil, F. Y. (2014). Pengaruh komitmen profesional dan sosialisasi antisipatif mahasiswa audit terhadap perilaku whistleblowing. Bisnis Dan Manajemen, 4(2), 198-209. https://doi.org/10.15408/ess.v4i2.1965

Libriani, E. W., \& Utami, I. (2015). Studi eksperimental tekanan ketaatan dan personal cost : dampaknya terhadap whistleblowing. Jurnal Akuntansi Dan Bisnis, 15(2), 106-119.

Pratiwi, H. (2019). Kisruh laporan keuangan Garuda Indonesia.

Rheny, H., \& Fajar, O. (2017). Pengaruh personal cost reporting , status wrong doer dan tingkat keseriusan kesalahan terhadap whistleblowing intention. Akuntansi Keuangan Dan Bisnis, 10(1), 11-20.

Rosiana, A., \& Pradnya, A. (2019). Pengaruh profesionalisme , komitmen organisasi dan sensitivitas etika terhadap intensi dalam melakukan whistleblowing: studi kasus pada Badan Pengelola Keuangan Dan Aset Daerah ( BPKAD ). Jurnal Ilmiah Akuntansi Dan Bisnis, 4(1), 1-13.

Sari, N., \& Yustina, T. (2018). Pengaruh audit tenure, debt default, kualitas audit dan opini audit terhadap opini audit going concern pada perusahaan manufaktur yang terdaftar di Bursa Efek Indonesia. Akuntansi, 7(1), 71-84.

Setianto, V. Y., Utami, I., \& Novianti, S. (2016). Whistleblowing dalam tekanan ketaatan dan kepercayaan pada pimpinan. Jurnal Ekonomi Dan Bisnis, 19(3), 485-511. https://doi.org/10.24914/jeb.v19i3.607

Setiawati, L. P., \& Sari, M. M. R. (2016). Profesionalisme, komitmen organisasi, intensitas moral dan tindakan akuntan melakukan whistleblowing. E-Jurnal Akuntansi Universitas Udayana, 17(1), 257-282.

Valen, M. A. (2018). Pengaruh kepatuhan auditor pada kode etik dan etika profesi terhadap kualitas audit (studi empiris pada Kantor Akuntan Publik di DKI Jakarta). Diponegoro Journal of Accounting, 7(4), 1-11. 